\title{
Japanese Monographs and Serials in the National Library of Medicine (USA)
}

\author{
Yoshiko Gotoh Doherty \\ Technical Information Specialist \\ National Library of Medicine \\ 8600 Rockville Pike, \\ Bethesda, Maryland 20894, USA \\ (Accepted March 26, 1996)
}

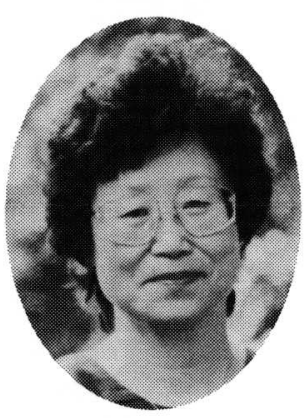

米国国立医学図書館 (NLM) は世界一の規模を誇る医学図書館である。1995 年末には, 70 か国語におよぶ 510 万を越える蔵書を有し, 文字どおり世界中からの資料を所蔵している。NLM の目的は, 生物医学研究者, 医療従事者に，有用な情報を提供することである。この目的達成に最も役立つ蔵書構築のために，NLM は Collection Development Manual を作成し，このカイドラインに基ついて，生物医学研究の重要な，あらゆる出 版物を世界中から収集するよう努めている。NLM の蔵書には約 21,500 冊の日本発行の図書および約 2,700 種 の日本発行の逐次刊行物雑誌が含まれており, うち約 1,500 種は受入れを継続中である。日本の逐次刊行物は, 米国, 英国, トイッに次いで，4番目に大きいコレクションであり，NLMにおいて日本のコレクションは重 要な情報資源のひとつである。

The National Library of Medicine (NLM) is the largest medical research library in the world. At the end of 1995 it held over 5.1 million items in over 70 languages from virtually every country in the world. NLM selects and acquires monographs and serials following carefully its Collection Development Manual to provide the most useful collection of important information to biomedical and health care professionals. NLM attempts to collect all significant biomedical research publications throughout the world. The collection includes an estimated 21,500 Japanese monographs and over 2,700 Japanese serial titles of which approximately 1,500 are currently active. This Japanese serial collection is the Library's fourth largest after the United States, the United Kingdom and Germany. The Japanese collection at NLM is a hidden treasure.

(以下同)

\section{I . Introduction}

The National Library of Medicine (NLM) is located on the campus of the National Institutes of Health in Bethesda, Maryland. It is just outside of Washington, D.C., in a suburban setting. NLM is the largest medical research library in the world. At the end of 1995 it held over 5.1 million items in over 70 languages from virtually every country in the world. The collection comprises over 665,000 biomedical and health related monographs, and over 74,000 serial titles. Included are an estimated 21,500 Japanese monographs and over 2,700
Japanese serial titles. Of these, approximately 1,500 are currently received Japanese serials. NLM acquires 500 to 600 Japanese monographs and 20 to 30 new Japanese serial titles every year.

\section{Collection Development Policy at the National Library of Medicine}

The Collection Development Manual of the National Library of Medicine (CDM), 3rd edition, was published in 1993. ${ }^{1)}$ The manual was written to assist and guide NLM staff so that collection practices are consistent among selectors and also to 


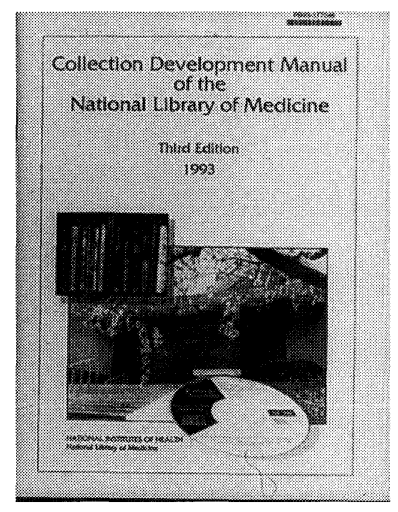

explain NLM's collecting practices to its users. The new edition is a reflection of the most recent trends in biomedicine. Selectors at NLM follow these guidelines when they select and acquire materials for NLM.

The manual states: "NLM's primary mission, as mandated by the Congress, is service to the health professional." ${ }^{2)}$ Included among health professionals are the following: 1. health care providers, 2. health administrators, 3 . biomedical researchers, 4. health educators and information professionals, 5. historians of medicine, and 6. individuals involved in health policy and health services research. ${ }^{3}$

To fulfill its mandate to serve the present and future information needs of health professionals, the Library is directed to "concentrate its collecting efforts on the biomedical literature without being limited by present perceptions and recognizing that the boundaries of the literature are constantly changing." 4)

The manual recognizes that not even a library as large as NLM can hope to acquire all materials related to biomedicine. It states:

"Coverage of the scholarly biomedical literature shall be comprehensive; coverage of other biomedical literature may be more selective. The intent is to ensure that the collection represents the intellectual content and diversity of the world's biomedical literature. In determining coverage, NLM will take into consid- eration its role as the national resource for the provision of biomedical literature not otherwise readily available, and as the national bibliographic center for biomedical literature for the health professions". ${ }^{5)}$

The manual also reminds the selector of the $\mathrm{Li}$ brary's responsibility for "acquiring the biomedical literature in any format deemed appropriate to the fulfillment of its mission". ${ }^{6}$ This is important in giving NLM the flexibility to respond to changing publication trends, particularly electronic modes of publication.

\section{Japanese Monograph Collection}

NLM selects and acquires monographs and other materials following its $C D M$ in an effort to provide the most useful collection of important information to biomedical and health care professionals. Japanese book selection has to follow the same guidelines. NLM strives for a comprehensive collection of works containing original research, regardless of language. Of particular interest are works discussing public health and health policy issues and works which describe indigenous medical disorders and approaches to treatment. Synthetic or secondary literature (such as textbooks) is collected more selectively.

The acquisition reference tool for Japanese books is “日本全国書誌：国立国会図書館”(the Japanese National Bibliography Weekly List) (JNBWL) published by National Diet Library. Occasionally publishers' pamphlets or catalogs are consulted. Most books are first identified through the section on "Medicine \& Pharmacology" in the JNBWL by NLM's Japanese dealer, and these books are sent to NLM on approval. When books arrive, they are reviewed by the Japanese selector to determine if they are appropriate to be added to the NLM's collection according to the $C D M$.

NLM does not usually collect books written for lay audiences. Occasionally, however, NLM 
collects well edited or unique examples of books on folk remedies, or offering historical insights on the experiences of physicians or patients. One example is, “脳死と心蔵移植一あれから 25 年 : 和田寿郎 著” (Brain Death and Heart Transplantation after those 25 years written by Juro Wada). This essay was written for a broad audience, not only for professionals. However, NLM collected this work, because Dr. Wada is a well respected heart surgeon and researcher, and this book discusses his unique experiences and his philosophy on controversial issues in Japan. It is also a reflection of medical ethics in contemporary Japanese culture.

NLM also collects publications that reflect cultural influences on medical practices. For example, it is reported in the United States from time to time that the Japanese communicate information through comic or cartoon publications - not only for children, but also for sophisticated adults. Some excellent comics were found that explain complex medical topics. "Comprehension through Comic Series” published by Raifu Saiensu (Tokyo) was listed in $J N B W L$, and interestingly it has an English series title. This series presents a unique way to provide basic and recent biomedical information in sufficient detail to lay people or to physicians who do not specialize in that field. Hard to understand medical terms or subjects become understandable through dramatized comics, which provide correct medical data with the stories. Of course, NLM does not intend to collect the entire series comprehensively as it would collect a substantive medical series, but “Vol. 1 高脂血症へのアブ ローチ: 青木鉄大 (コミックス)” (An Approach to Hyperlipidemia - comics by Tetsuo Aoki) and “Vol. 2 高血圧へのアプローチ：佐々木あつし (コミック)”(An Approach to Hypertension-comics by Atsushi Sasaki), were collected as examples which show the influence of the Japanese comic culture in the biomedical field. These may have historical interest 100 years from now.

As explained previously, NLM depends prin- cipally on the $J N B W L$ for identification of monographic publications. Since books usually are not listed in $J N B W L$ until four to twelve months after publication, there is a delay between publication, citation in the $J N B W L$ and NLM's acquisition. This delay can be a critical problem, especially for privately issued publications. It is often too late to acquire some publications which are issued as limited editions, and, in any case, they may not be available commercially at all. For example, a private publication series entitled “世界の薬用植物 : 西村秀敏著” (Medicinal Plants in the World by Hidetoshi Nishimura) was cited in JNBWL in 1994. NLM first attempted to acquire the title through a Japanese dealer. The dealer could not provide the first and second volumes because they were limited editions and not for sale. Since the dealer provided the author's address, the author was contacted and given an explanation of the NLM's mission and collection purpose, and was asked if he would make upcoming volumes of his work available to the Library since they could not be acquired commercially. At first the author was reluctant to part with his last copies of the previously published volumes, however, NLM was later surprised and gratified to receive the first three volumes of this privately published series and NLM will be able to add the complete set to its collection. It will now be available to health professionals in the United States. This is one of the more fortunate stories, but on many occasions NLM has to give up attempts to collect certain books or to fill gaps in series because the publications are no longer available. If a title is not listed in $J N B W L$, NLM has much less chance of finding out about its existence. Fortunately, unique publications sometimes are donated by individuals. NLM appreciates those donations that fall within its collection development guidelines. 


\section{Japanese Serial Collection}

NLM's strives insofar as possible to collect all significant biomedical serials from throughout the world. NLM's emphasis in collecting from Japan, as from other foreign countries, is on quality research journals, that is journals predominantly devoted to reporting original investigations in the biomedical and health sciences, such as clinical trials of therapeutic agents, effectiveness of diagnostic or therapeutic agents, or studies relating to the behavioral, epidemiologic or education aspects of medicine. NLM also collects scholarly journals in the history of medicine and journals which cover national health policy or document the state of medical care and practice in Japan. NLM is particularly interested in scholarly publications sponsored by Japanese medical professional societies and important research institutions.

Selected trade publications, Japanese government annual reports and annual research reports of pharmaceutical companies, bulletins or medicallyrelated training and nursing schools are also included in the collection if they contain important research, clinical, policy or statistical information. Some unique newsletters also are relevant such as one which is written and edited by patients in a leprosy rehabilitation institute.

To acquire serials from Japan, NLM relies principally on a commercial vendor; however, the $\mathrm{Li}$ brary also benefits from a number of gift and exchange agreements with public or private institutes, or professional societies. Every few years, when “日本科学技術関係逐次刊行物総覧：国立 国会図書館”（the Directory of Japanese Scientific Periodicals) is published, NLM checks it to make sure that the important and most recent periodicals are not missed. NLM also makes every attempt to identify journals sponsored by professional medical societies, which often do not appear in this directory.

As can be seen from Table 1, the serials collection
Table 1. Countries with largest number of serials at NLM

\begin{tabular}{lcc}
\hline \multicolumn{1}{c}{ Country } & Open serials & W1 serials \\
\hline United States & 12,201 & 5,203 \\
United Kingdom & 2,511 & 1,607 \\
Germany & 1,940 & 1,448 \\
Japan & 1,476 & 1,196 \\
France & 1,041 & 638 \\
Italy & 859 & 590 \\
Canada & 519 & 252 \\
China & 450 & 336 \\
Korea & 366 & 160 \\
\hline & & (Nov. 1995)
\end{tabular}

of 1,476 current Japanese titles is the Library's fourth largest, ranking after only the United States, the United Kingdom and Germany. Of these, 1,196 of the Japanese titles are classed in NLM's form number W1 compared with 5,203 from the United States, 1,607 from the United Kingdom, 1,448 from Germany and 638 from France. The $\mathrm{W} 1$ form number includes serials as defined by the Anglo-American Cataloguing Rules, second edition, revised 1988, except for government administrative reports or statistics (W2), hospital administrative reports or statistics (WX2), directories, handbooks, etc. (monographic treatment), and bibliographies and indexes. ${ }^{7)}$

NLM holds long runs of some Japanese journal titles. “日本内科学会誌” (the Journal of Japanese Society of Internal Medicine) 1913-, “日本眼科学 会誌” (Acta Societatis Ophthalmologicae Japonicae) 1897-, “薬学雑誌” (Journal of the Pharmaceutical Society of Japan) 1881-, “順天堂医事会 雑誌” (Juntendo Ijikai Zasshi) 1898- and “慶応 医学” (Journal of the Keio Medical Society) 1921are some examples. These Japanese medical journals are not as old as some European periodicals because the influence of western medicine and its methods for publishing medical research was not felt in Japanese society until the late 1800s, long after it was established in European society. NLM's holdings of the early issues of Japanese journals (from the first issue) are significant and are 
worth mentioning from an historical perspective.

Recently NLM reviewed the Japanese serial collection. All currently received Japanese serials were re-evaluated to determine if all met collecting guidelines according to the new CDM. Because of changes in its collection development policy, NLM decided to discontinue some journals.

Sometimes it is a difficult decision to determine which titles to keep and which to eliminate. Most sciences are related to medical or health sciences although not always directly. In years past, NLM tried to collect many pure and applied science journals. In recent years, it has become impossible to collect comprehensively all sciences for reasons of finances and preservation space limitations. Since the 3rd edition of the Collection Development Manual was published, NLM collects only the biomedical aspects of broad natural science subjects such as chemistry, physics and botany. For example, general botany is not collected, but medical botany is collected comprehensively. Similarly, journals covering organic chemistry are not collected, while journals of biochemistry are collected. When a journal covers several aspects of chemistry, the selector makes a decision based on the proportion of biomedical to non-biomedical articles carried in the publication. For the same reason, some magazines for general, nonprofessional audiences were eliminated also.

\section{Conclusion}

This article was written about the author's practice and experience during her first three years at the National Library of Medicine as a Japanese selector. Surprisingly to the author, the volume of Japanese works collected in NLM is large, but relatively unknown to those who might find it of interest. The author considers this collection a hidden treasure. If this article helps a little to publicize the Japanese collection and to make it more widely used, this article meets one of its goals.

The author wishes to thank Carol Krueger, NLM serials librarian, for providing periodical statistics.

The author would like to dedicate this article to her father on his 90th birthday.

\section{Reference}

1) Arenales D, Byrnes M, Eannarino J et al. Collection Development Manual of the National Library of Medicine ; 3rd ed. Bethesda, Maryland : U.S. Dept. of Health and Human Service, Public Health Service, National Library of Medicine, 1993.

2) Ibid. p. 1 .

3 ) Ibid. p. 3 .

4) Ibid. p. 3.

5 ) Ibid. p. 2.

6) Ibid. p. 2

7 ) National Library of Medicine Classification ; 5th ed. Bethesda, Maryland : U.S. Dept. of Health and Human Service, Public Health Service, National Library of Medicine, 1994 : p. xiv. 